DOI https://doi.org/10.18551/rjoas.2020-10.04

\title{
THE EFFECT OF VILLAGE FUND, PAD, AND EDUCATION ON ECONOMIC GROWTH AND POVERTY LEVEL OF DISTRICT / CITY IN BALI PROVINCE, INDONESIA
}

\author{
Prasetya I Gede Eka Dita, Yasa I Nyoman Mahaendra \\ Faculty of Economics and Business, University of Udayana, Bali, Indonesia \\ ${ }^{\star}$ E-mail: prasetya.gd@gmail.com
}

\begin{abstract}
Poverty is global problem that faced by all country, especially in developing countries such as Indonesia, including Bali Province. Although Bali Province has a good economic growth rate and poverty rate on a national scale, but there is imbalance at districts/cities level. Lack of development capital to create jobs and implement welfare improvement programs, as well as the low quality of education in human resources (HR) are the causes of imbalance economic growth and poverty. Village Fund (DD) is a government policy to accelerate equitable development by creating jobs. Regional Original Income (PAD) is one of the sources used to finance welfare improvement programs. The quality of human resource education is an important factor in increasing economic growth and poverty alleviation. This study aims to analyze the effect of village funds (DD), Regional Original Income (PAD), and education on economic growth and poverty in districts/cities in Bali by using secondary data sourced from the Central Statistics Agency (BPS) and the Directorate General of Finance Region (DJKP) of the Indonesia Ministry of Finance, by time series data of 2015-2019 which analyzed using path analysis techniques. The results of this study indicate that DD significantly has no positive effect on economic growth, PAD and education level have a positive effect but insignificant on economic growth. DD has negative and insignificant effect on the poverty level, PAD and education level has negative effect significantly on the poverty level. Indirectly, the variables DD, PAD, and education level did not significantly effect to the poverty level through economic growth.
\end{abstract}

\section{KEY WORDS}

Village fund, regional original income, education, economic growth, poverty.

Poverty reduction is a global issue that should get serious attention as stated in the Sustainable Development Goals (SDG's), as it states that the first goal is to end poverty anywhere and in all forms. The target of SDG's first objective in Indonesia is to eradicate extreme poverty (people below the poverty line) with a purchasing power of less than USD 1.25 and ensure that all residents, especially the poor and vulnerable, have the same rights in accessing economic resources, ownership and access to land, and gain access to technology (SDG's, 2020).

The poverty rate in Indonesia tends to decline in the 2015-2019, where the poverty rate in 2015 was 11.13 percent and in 2019 was 9.22 percent. The poverty rate in Indonesia in 2018 is an achievement from the government because for the first time in history can reduce the poverty rate to single digits and in 2019 the poverty rate was 9.22 percent which is the lowest in history. However, in absolute terms, the number of poor people in Indonesia in 2019 based on BPS data is still quite high, 24,785 million people.

Poverty is a complex problem that is negative in nature and has a negative impact on the progress of a region so that the problem of poverty must be eradicated to its roots (Wirawan, 2015). The high number of poor people in Indonesia in absolute terms shows the government's strategy in reducing poverty is not optimal yet.

Bali as one of the province in Indonesia which has high economic growth, are not emancipated from the problem of poverty. The Bali Province which is known as the island of the gods or the island of a thousand temples is a world tourist destination. With high economic growth rate above the national economic growth rate with the tourism industry sector as the main contributor to PRDB in Bali, there are still poor people in Bali. 
The rate of economic growth in all districts/cities of Bali Province in 2015-2019 has a fluctuating trend, but tends to decline. Klungkung Regency is the district with the lowest economic growth rate in 2019, about 5.44 percent and the highest is Denpasar City with an economic growth rate of 5.84 percent. However, on average, the economic growth rate in Bali Province in 2019 was 5.63 percent, which is still above the national economic growth rate of 5.02 percent. Although the rate of economic growth in Bali Province is quite high, there is an imbalance in the number of poor people in districts/cities in Bali Province, which reflects that the income is uneven for Bali resident.

The growth of the number of poor people and the level of poverty in districts/cities in Bali Province in 2015-2019 tends to decline. However, during that period, there was an imbalance in the level of poverty between districts/cities in Bali Province. Distribution of poor people in Bali in 2015-2019 by region, where the number of poor people in urban was more than in rural areas during that period. However, in percentage terms, the poverty rate in rural areas was higher than the poverty rate in urban areas. The poverty rate in urban areas tended to decline during that period, but in absolute terms there was an increase in the number of poor people from 2018 to 2019 of 3.95 thousand people. Urban residents benefit more from the progress of economic development compared to residents in rural areas (Fan et al., 2004). This explains that poverty reduction is not evenly distributed across different regions.

The role of local governments in reducing poverty in Bali Province through regional development policies is urgently needed. Various policies have been implemented by the government, both central and local governments, to reduce poverty and increase people's income, but they have not been able to reduce poverty levels evenly in all districts/cities in Bali Province. The different characteristics in each district / city in Bali requires different strategies and measures to accelerate poverty reduction in the regions. Law No. 32 of 2004 about Regional Government which has been amended to Law No. 23/2014 about Regional Government has provided a legal basis for local governments to implement regional autonomy and decentralization.

The right policies are needed to reduce income inequality so that the poor can benefit from economic growth (Adelowokan et al., 2019). Poverty alleviation strategies will require large-scale public policies and actions that should not only focus on growth, but also increase the distribution of the impact of economic growth (Michalek, 2018).

According to Nurske (1953), lack of capital is one of the causes of poverty. Capital within the scope of local government is a financial resource to finance program activities aimed at improving community welfare and reducing poverty. Financial capital for local governments is obtained from several sources of regional financial revenue as regulated by law. One source of revenue for local governments is Original Local Government Revenue (PAD). According to Law Number 33 of 2004 concerning Financial Balance between the Central and Regional Governments, PAD is revenue obtained by regions which is collected based on regional regulations in accordance with statutory regulations which originates from: local taxes, regional levies, profits from BUMD, and the other legal regional original revenue.

Jolianis' (2016) research results suggest that PAD has a positive and significant effect on economic growth and has a negative and significant effect on poverty. The contribution of PAD to the APBD is a measure of a region's economic growth. The higher the PAD, the more flexible for regional government to plan budget allocations in accordance with the regional economic agenda as outlined in regional development planning documents. PAD as a source of regional income is used to finance regional expenditure, both for development and infrastructure spending, education spending and other expenditures which are expected to be able to create and increase economic activity in the community. An increase of community economic activity due to government spending will increase the total output of goods and services, followed by an increase in public income.

Spending on infrastructure will also provide the resources needed by the private sector to grow and succeed in the long term. Education spending for human capital investment is the most important resource for a country to increase economic growth in the long run. Government spending contributes to long-term economic growth (Mahaendra Yasa et al., 
2018). This condition will encourage regional economic growth, increase GRDP, increase community welfare, and reduce poverty.

Law No. 6/2014 about Villages provides a legal basis for new paradigms and concepts of village governance policies. Village is the subject and spearhead of development and improvement of community welfare. Villages are given the authority to regulate and manage government affairs, the interests of the local community based on community initiatives, rights of origin, traditions, and socio-cultural values of the village community. The Indonesian government, through its third nawacita, is committed to developing Indonesia from the periphery by strengthening regions and villages within the framework of a unitary state, among others by increasing development in villages to accelerate equitable rural development, creating jobs, increasing people's income and purchasing power, and alleviate poverty. Villages are also given sources of village financial revenue in the form of transfer funds, one of which is village funds.

Village funds are prioritized to finance the development and empowerment of rural communities, especially for improving the quality of life, poverty alleviation, and community well-being. The use of village funds is basically the right of the village government in accordance with the authority and priority needs of the local village community while still advancing the principles of justice. In line with the achievement of village fund utilization output including the provision of physical infrastructure development, provision of public services especially for rural communities, as well as support for rural economic development, it is expected to have an impact on increasing income and welfare of the community. Village fund management is the key to rural scale economic growth, if village funds are well managed from the planning, implementation, to accountability stage, then various economic potential in the village will grow well. By economic growth of village increased, it will encourage economic growth of the region and reduce the number of poor people at the regional and national levels.

In addition to funding sources for running poverty alleviation programs and job creation, another factor influencing poverty is education. Education is a pioneer in future development (Wirawan, 2015). Education is a basic development goal and the main thing to achieve a satisfying and valuable life. Education is one of the human resource investments to get a better life. Better education will increase productivity and higher incomes will be easier to achieve. Education is one of the basic human capital that must be met in order to achieve sustainable economic development (Todaro, 2006).

Poverty that occurs in households is caused by low education (Margareni, 2016). Education is seen as an investment whose results can be obtained several years later by work output increased, which affects productivity levels (Amalia, 2012). Through adequate education, the poor will have a better chance of getting out of poor status in the future (Anderson, 2013). Education is an important indicator of economic growth and poverty (Margareni, 2016). The formation of human capital through improving the quality of education is the main capital for development (Arsyad, 2016). Improving the quality of education can improve the quality and productivity of society. This is what drives economic growth and social welfare. According to Todaro (2006), people's welfare is positively related to per capita income, but negatively related to poverty and inequality.

Economic growth can show how far the economic activity will generate additional income for the community in a certain period. Economic growth is one of the factors that can affect poverty reduction. Economic growth that needed is not only high growth, but also evenly distributed to all levels of society (Pratiwi, 2014). This is in line with the development strategy initiated by the world bank, the development and growth approach with equity (redistribution with growth) and the ILO (International Labor Organization) offers a basic need approach as a solution (Asryad, 2016). The approach that considered quite appropriate in poverty reduction is to create economic activity in the region which is marked by the region's ability to create economic growth (Manek, 2016).

The main sources for economic growth are investments that are able to improve the quality of capital, or human, and physical resources, which in turn has succeeded in increasing the quantity of productive resources and increasing the productivity of all 
resources through new discoveries, innovations and technological advances (Todaro, 2006). The source of growth does not only depend on the accumulation of labor and capital, but also from the contribution of community productivity (total factor productivity).

\section{METHODS OF RESEARCH}

The purpose of this study is to analyze the effect of village funds, PAD, and education levels on economic growth and poverty levels in districts/cities in Bali Province. The research design that used in this study is a quantitative research design with associative form which explains the relationship between two or more variables.

This study uses five variables, village funds, PAD, education level, economic growth, and poverty levels in causality. The poverty level is an endogenous variable influenced by exogenous variables Village funds, PAD, and education level. Economic growth is as an intervening variable. In quantitative research, the method used to explain the causality between variables is through hypothesis testing.

The type of data used in the analysis in this study is secondary data in the form of panel data on nine districts/cities in Bali Province for 2015 to 2019 with a total of 45 observation points. Data sources were obtained from the central BPS, Bali Province BPS, district / cities BPS in Bali Province, Bappeda of Bali Province, Office of Community Empowerment, Village, Population and Civil Registry of Bali Province, and Directorate General of Fiscal Balance, Ministry of Finance of the Republic of Indonesia. The data that has been collected will be processed using descriptive statistical analysis techniques and path analysis.

This study uses three types of variables, i.e. exogenous variables, intervening variables, and endogenous variables where these variables are grouped as follows:

1. Exogenous variables are variables that influence or cause changes or the emergence of endogenous variables. In this study, the exogenous variables included village funds $\left(X_{1}\right)$, PAD $\left(X_{2}\right)$, and education level $\left(X_{3}\right)$.

2. Intervening variables are variables that theoretically affect the relationship between exogenous and endogenous variables into an indirect relationship that cannot be observed and measured. This variable is an intermediate variable that lies between exogenous and endogenous variables, so that exogenous variables do not directly influence changes in endogenous variables. In this study, the intervening variable is economic growth $\left(Y_{1}\right)$.

3. Endogenous variables are variables that affected or the result of exogenous variables. In this study, the poverty rate $\left(\mathrm{Y}_{2}\right)$ was used as an endogenous variable.

In path analysis, there is a variable that can play a dual role, as an independent variable in a relationship, but becomes a dependent variable in another relationship (Suyana Utama, 2010). The variable that has multiple functions is called the mediating or intervening variable. The reasons for using path analysis techniques as follows:

1. The tested hypothesis is developed with a model (conceptual framework) where all the relationships are asymmetrical and systematic, and the model can be categorized as recursive so that the most appropriate method is path analysis.

2. Path analysis provides a direct method of dealing with multiple simultaneous relationships (structural models) that provide efficient statistical analysis.

3. The ability to examine the relationship comprehensively and provide a transition from exploratory analysis to confirmatory analysis. These are best solved by path analysis.

Designing models based on previous concepts, theories, and research:

a. Village funds affect on economic growth in regencies / cities in Bali Province.

b. PAD affect on economic growth in districts/cities in Bali Province.

c. Education level has an effect on economic growth in districts/cities in Bali Province.

d. Village funds have an effect on poverty levels in districts/cities in Bali Province.

e. PAD affect on poverty level in districts/cities in Bali Province.

f. Education level has an effect on the poverty level in districts/cities in Bali Province.

g. Economic growth affects the poverty level in districts/cities in Bali Province. 

follows:

The relationship between variables on the description above can be described as

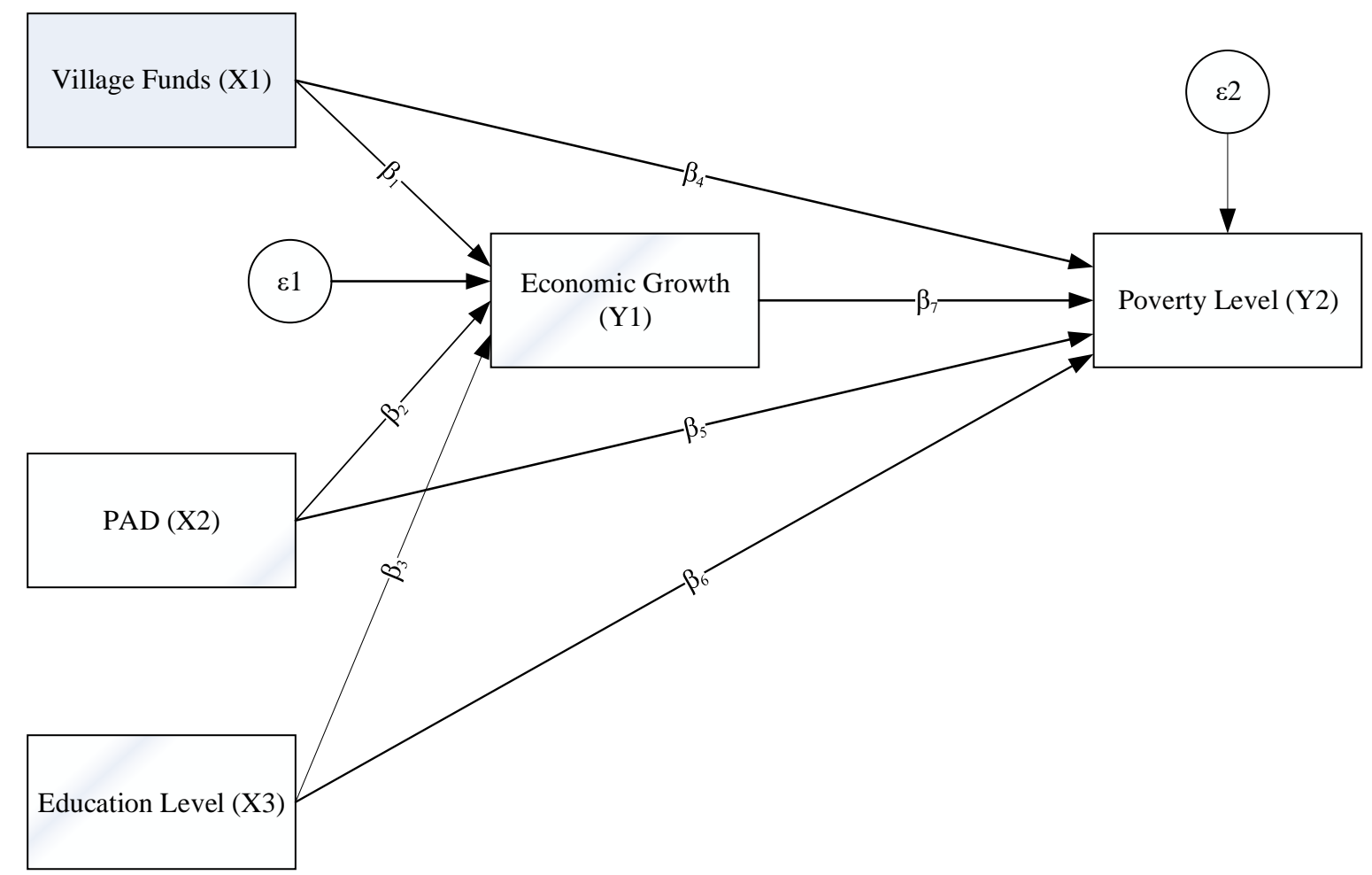

Figure 1 - Research Path Diagram Effect of Village Funds, PAD, and Education on Economic Growth and Poverty

The model also can be expressed in equation form as follows:

$$
Y_{1}=\beta_{1} X_{1}+\beta_{2} X_{2}+\beta_{3} X_{3}+e_{1}
$$

Where:

- $Y_{1}$ is a variable of economic growth;

- $\mathrm{X}_{1}$ is the village fund variable;

- $X_{2}$ is the PAD variable;

- $X_{3}$ is a variable level of education;

- $\beta_{1}$ is the path coefficient of $X_{1}$ and $Y_{1}$;

- $\beta_{2}$ is the path coefficient of $X_{2}$ and $Y_{1}$;

- $\beta_{3}$ is the path coefficient of $X_{3}$ and $Y_{1}$.

$$
Y_{2}=\beta_{4} X_{1}+\beta_{5} X_{2}+b_{6} X_{3}+b_{7} Y_{1}+e_{2}
$$

Where:

- $\mathrm{Y}_{2}$ is the poverty level variable;

- $Y_{1}$ is a variable of economic growth;

- $\mathrm{X}_{1}$ is the village fund variable;

- $X_{2}$ is the PAD variable;

- $X_{3}$ is a variable level of education;

- $\beta_{4}$ is the path coefficient of $X_{1}$ and $Y_{2}$;

- $\beta_{5}$ is the path coefficient of $X_{2}$ and $Y_{2}$;

- $\beta_{6}$ is the path coefficient of $X_{3}$ and $Y_{2}$;

- $\quad \beta_{7}$ is the path coefficient of $Y_{1}$ and $Y_{2}$. 
In the path analysis model, the relationship between variables is linear and additive, the causal flow system is one-way, the endogenous variables / bound in the interval measuring scale minimally, the observations are measured without errors, the analyzed model is correctly identified based on theories and concepts relevant, and linearity test using curve fit and applying the parsimony system, if all models are significant or insignificant, it means that the model is linear.

Estimation of parameters (path coefficient), where if the arrow shows a back and forth direction it means a correlation coefficient, if the arrow shows one direction it usually uses the OLS (Ordinary Least Square) method, in path analysis in addition to direct influence there is also an indirect effect and total influence. The beta coefficient is called the path coefficient which is a direct effect, while the indirect effect is carried out by multiplying the beta coefficient of the variable traversed. The total effect is calculated by adding the direct effect and the indirect effect.

The model validity indicator used is the total coefficient of determination which is the total diversity of data that can be explained by the model measured by $R_{m}^{2}=1-P_{e 1}^{2} P_{e 2}^{2} \ldots P_{e p}^{2}$.

Interpretation is same with interpretation of the coefficient of determination $\left(R^{2}\right)$ in the regression analysis.

$\mathrm{P}_{\mathrm{ei}}$ which is the standard error of estimate from the regression model calculated by the formula $P_{e i}=\sqrt{1-R^{2}}$

Calculation of path coefficients using SPSS (Static Product and Service Solution) software version 26.0 through partial regression analysis where the path coefficient is a standardized regression coefficient (standardized coefficients beta) for its direct effect. The indirect effect is the multiplication of coefficient path which each equation follows and the total of direct effect an indirect effect.

The purpose of path analysis beside to know the direct effect of a variable with other variables, is also to determine the role of a variable to mediate a variable on other variables. Mediating or intervening variables are variables that mediate the relationship between exogenous and endogenous variables bound through an indirect relationship. Testing the effect of intervening variables can be done by testing developed by Sobel, hereinafter known as the Sobel test. Baron and Kenny (1986) in Ghozali (2008) state that a variable is called an intervening variable if the variable influence the relationship between the independent variable and the dependent variable.

Sobel test are done by testing the strength of the indirect effect of the exogenous variable $(X)$ on the endogenous variable $(Y)$ through the intervening variable $(M)$. The Sobel test $(\mathrm{Sab})$ is calculated using the formula:

$$
\mathrm{Sab}=\sqrt{b^{2} S a^{2}+a^{2} S b^{2}}
$$

Where:

- $\quad a b$ : the coefficient of indirect effect obtained from multiplying the direct effect $a$ and $b$;

- a: the coefficient of independent direct effect $(X)$ on the mediator $(M)$;

- b: coefficient of direct effect mediator $(\mathrm{M})$ to dependent $(\mathrm{Y})$;

- Sa: standard error of the coefficient a;

- Sb: standard error of the coefficient $b$.

The significance test of the indirect effect, then need to calculate the t value of the $a b$ coefficient with the following formula: $z$-value $=\frac{a b}{S a b}$.

To find out the hypothesis test by comparing the p-value and alpha $(0,05)$ with the following conditions:

1. If the $p$-value $\geq$ alpha $(0.05)$, or $z$ count $\leq(z$ table $=1.96)$, then $H_{0}$ is accepted, which means $M$ is not the mediating variable;

2. If the $p$-value <alpha $(0.05)$, or $z$ count $>(z$ table $=1.96)$, then $H_{0}$ is rejected, which means $M$ is the mediating variable. 


\section{RESULTS OF STUDY}

Table 1 - Poverty rate of districts/cities in Bali Province 2015-2019 (in \%)

\begin{tabular}{cccccc}
\hline District/City & \multicolumn{5}{c}{ Year } \\
\cline { 2 - 5 } & 2015 & 2016 & 2017 & 2018 & 2019 \\
\hline Jembrana & 5.84 & 5.33 & 5.38 & 5.20 & 4.88 \\
Tabanan & 5.52 & 5.00 & 4.92 & 4.46 & 4.21 \\
Badung & 2.23 & 2.06 & 2.06 & 1.98 & 1.78 \\
Gianyar & 4.61 & 4.44 & 4.46 & 4.19 & 3.88 \\
Klungkung & 6.91 & 6.35 & 6.29 & 5.86 & 5.40 \\
Bangli & 5.73 & 5.22 & 5.23 & 4.89 & 4.44 \\
Karangasem & 7.44 & 6.61 & 6.55 & 6.28 & 6.25 \\
Buleleng & 6.74 & 5.79 & 5.74 & 5.36 & 5.19 \\
Denpasar & 2.39 & 2.15 & 2.27 & 2.24 & 2.10 \\
\hline Bali Province & 4.74 & 4.25 & 4.25 & 4.01 & 3.79 \\
\hline
\end{tabular}

Source: BPS Bali Province, 2020.

Table 2 - Economic Growth of districts/cities in Bali Province 2015-2019 (in \%)

\begin{tabular}{cccccc}
\hline \multirow{2}{*}{ District/City } & \multicolumn{5}{c}{ Year } \\
\cline { 2 - 5 } & 2015 & 2016 & 2017 & 2018 & 2019 \\
\hline Jembrana & 6.19 & 5.96 & 5.28 & 5.59 & 5.56 \\
Tabanan & 6.19 & 6.14 & 5.37 & 5.73 & 5.60 \\
Badung & 6.24 & 6.81 & 6.08 & 6.74 & 5.83 \\
Gianyar & 6.30 & 6.31 & 5.46 & 6.03 & 5.64 \\
Klungkung & 6.11 & 6.28 & 5.32 & 5.50 & 5.44 \\
Bangli & 6.16 & 6.24 & 5.31 & 5.50 & 5.47 \\
Karangasem & 6.00 & 5.92 & 5.06 & 5.48 & 5.50 \\
Buleleng & 6.07 & 6.02 & 5.38 & 5.62 & 5.55 \\
Denpasar & 6.14 & 6.51 & 6.05 & 6.43 & 5.84 \\
\hline Bali Province & 6.03 & 6.33 & 5.56 & 6.33 & 5.63 \\
\hline
\end{tabular}

Source: BPS Bali Province, 2020.

Table 3 - Village Fund (DD) of districts/cities in Bali Province 2015-2019 (in million rupiah)

\begin{tabular}{cccccc}
\hline District/City & \multicolumn{5}{c}{ Year } \\
\cline { 2 - 5 } & 2015 & 2016 & 2017 & 2018 & 2019 \\
\hline Jembrana & 12,410 & 27,863 & 36,476 & 39,392 & 49,043 \\
Tabanan & 37,069 & 83,184 & 106,418 & 101,722 & 118,205 \\
Badung & 13,826 & 31,047 & 40,316 & 42,303 & 52,585 \\
Gianyar & 19,167 & 43,036 & 55,754 & 51,972 & 59,992 \\
Klungkung & 15,261 & 34,259 & 44,540 & 43,276 & 51,534 \\
Bangli & 19,198 & 43,090 & 55,784 & 52,858 & 61,335 \\
Karangasem & 21,963 & 49,302 & 63,683 & 64,240 & 78,719 \\
Buleleng & 36,813 & 82,620 & 105,861 & 107,040 & 124,027 \\
Denpasar & 9,723 & 21,863 & 28,428 & 27,405 & 34,750 \\
\hline Total of Bali & 185,429 & 416,265 & 537,259 & 530,206 & 630,190 \\
\hline
\end{tabular}

Source: BPS Bali Province, 2020.

Table 4 - PAD Realization of districts/cities in Bali Province 2015-2019 (in million rupiah)

\begin{tabular}{cccccc}
\hline \multirow{2}{*}{ District/City } & \multicolumn{5}{c}{ Year } \\
\cline { 2 - 5 } & 2015 & 2016 & 2017 & 2018 & 2019 \\
\hline Jembrana & 98,160 & 114,533 & 121,342 & 126,477 & 133,698 \\
Tabanan & 300,799 & 318,085 & 426,636 & 363,370 & 354,558 \\
Badung & $3,001,464$ & $3,563,586$ & $4,172,457$ & $4,555,716$ & $4,835,188$ \\
Gianyar & 457,321 & 529,865 & 697,997 & 770,205 & 997,478 \\
Klungkung & 120,033 & 134,772 & 153,234 & 186,974 & 224,510 \\
Bangli & 87,802 & 104,829 & 104,592 & 122,686 & 127,040 \\
Karangasem & 243,126 & 232,644 & 198,664 & 200,362 & 233,013 \\
Buleleng & 293,038 & 282,114 & 455,195 & 335,555 & 365,852 \\
Denpasar & 776,214 & 807,042 & $1,008,710$ & 940,110 & $1,010,779$ \\
\hline Bali Province & $3,041,298$ & $3,041,192$ & $3,398,472$ & $3,718,094$ & $3,587,699$ \\
\hline
\end{tabular}

Source: BPS Bali Province, 2020. 
Table 5 - Education level based on the average length of schooling districts/cities in Bali Province 2015-2019 (in years)

\begin{tabular}{cccccc}
\hline \multirow{2}{*}{ District/City } & \multicolumn{5}{c}{ Year } \\
\cline { 2 - 6 } & 2015 & 2016 & 2017 & 2018 & 2019 \\
\hline Jembrana & 7.54 & 7.59 & 7.62 & 7.95 & 8.22 \\
Tabanan & 8.07 & 8.10 & 8.43 & 8.64 & 8.87 \\
Badung & 9.44 & 9.90 & 9.99 & 10.06 & 10.38 \\
Gianyar & 8.49 & 8.86 & 8.87 & 8.92 & 8.94 \\
Klungkung & 6.98 & 7.06 & 7.46 & 7.75 & 8.12 \\
Bangli & 6.41 & 6.44 & 6.80 & 7.13 & 7.16 \\
Karangasem & 5.42 & 5.48 & 5.52 & 5.97 & 6.31 \\
Buleleng & 6.77 & 6.85 & 7.03 & 7.04 & 7.08 \\
Denpasar & 11.02 & 11.14 & 11.15 & 11.16 & 11.23 \\
\hline Provinsi Bali & 8.26 & 8.36 & 8.55 & 8.65 & 8.84 \\
\hline
\end{tabular}

Source: BPS Bali Province, 2020.

Table 6 - Descriptive analysis of the effect of DD, PAD, and education on economic growth and poverty of districts/cities in Bali Province

\begin{tabular}{llllll}
\hline & $\mathrm{N}$ & Minimum & Maximum & Mean & Std. Deviation \\
\hline $\operatorname{DD}\left(\mathrm{X}_{1}\right)$ & 45 & $9,723.00$ & $124,027.00$ & $51,096.71$ & $29,504.04$ \\
$\operatorname{PAD}\left(\mathrm{X}_{2}\right)$ & 45 & $87,802.00$ & $4,835,188.00$ & $770,840.58$ & $1,215,669.33$ \\
Education Level $\left(\mathrm{X}_{3}\right)$ & 45 & 5.42 & 11.23 & 8.12 & 1.62 \\
Economic Growth $\left(\mathrm{Y}_{1}\right)$ & 45 & 5.06 & 6.81 & 5.87 & 0.41 \\
Poverty Rate $\left(\mathrm{Y}_{2}\right)$ & 45 & 1.78 & 7.44 & 4.71 & 1.59 \\
Valid N (listwise) & 45 & & & & \\
\hline
\end{tabular}

Path analysis is used to determine the direct and indirect effects of a variable. In this study, to determine the effect of village funds, PAD, education level on poverty levels both directly and indirectly through economic growth on structural equation models as presented in the analysis technique using SPSS version 26.00 software, the obtained results of the analysis test as follows:

Table 7 - Path Analysis Results

\begin{tabular}{lccccc}
\hline Relation & Standard Regression Coefficient & Standard Error & t value & $P$ value & Result \\
\hline $\mathrm{X}_{1} \rightarrow \mathrm{Y}_{1}$ & -0.438 & 0.000 & -3.568 & 0.001 & Negative and significant \\
$\mathrm{X}_{2} \rightarrow \mathrm{Y}_{1}$ & 0.261 & 0.000 & 1.813 & 0.077 & Positive and significant \\
$\mathrm{X}_{3} \rightarrow \mathrm{Y}_{1}$ & 0.177 & 0.037 & 1.208 & 0.234 & Positive and significant \\
$\mathrm{X}_{1} \rightarrow \mathrm{Y}_{2}$ & -0.054 & 0.000 & -0.980 & 0.333 & Negative and insignificant \\
$\mathrm{X}_{2} \rightarrow \mathrm{Y}_{2}$ & -0.301 & 0.000 & -5.140 & 0.000 & Negative and significant \\
$\mathrm{X}_{3} \rightarrow \mathrm{Y}_{2}$ & -0.764 & 0.057 & -13.095 & 0.000 & Negative and significant \\
$\mathrm{Y}_{1} \rightarrow \mathrm{Y}_{2}$ & -0.002 & 0.234 & -0.035 & 0.973 & Negative and insignificant \\
\hline
\end{tabular}

Information: $Y_{2}$ is the poverty level; $Y_{1}$ is economic growth; $X_{1}$ is the village fund; $X_{2}$ is $P A D ; X_{3}$ is the level of education.

Testing with path analysis also shows the magnitude of the total effect, direct effect, and indirect effect of one to another variable which can be described as follows:

1. The direct effect of village funds on economic growth of districts/cities in Bali Province $=\beta_{1}=-0.438$.

2. The direct effect of PAD on economic growth of districts/cities in Bali Province = $\beta_{2}=0.261$.

3. The direct effect of education level on economic growth of districts/cities in Bali Province $=\beta_{3}=0.177$.

4. The direct effect of village funds on poverty levels if districts/cities in Bali Province $=$ $\beta_{4}=-0.054$.

5. The direct effect of PAD on the level of poverty of districts/cities in Bali Province = $\beta_{5}=-0,301$

6. Direct effect of education level on poverty levels of districts/cities in Bali Province $=$ $\beta_{6}=-0.764$

7. The direct effect of economic growth on poverty levels of districts/cities in Bali Province $=\beta_{7}=-0.002$. 
8. The indirect effect of village funds on poverty levels through economic growth of districts/cities in Bali Province is equal to $\beta_{1} \times \beta_{6}=-0.438 \times-0.002=0.000876$.

9. The indirect effect of PAD on poverty levels through economic growth of districts/cities in Bali Province is equal to $\beta_{2} \times \beta_{6}=0.261 \times-0.002=-0.000522$.

10. The indirect effect of education level on poverty levels through economic growth in districts/cities of Bali Province is equal to $\beta_{3} \times \beta_{6}=0.177 \times-0.002=-0.000354$.

11. Total effect is the sum of direct effects and all indirect effects.

a. The effect of total village funds on poverty levels through economic growth of districts/cities in Bali Province is equal to $-0.054+0.000876=-0.053124$.

b. The effect of total PAD on poverty levels through economic growth of districts/cities in Bali Province is equal to $-0.301+(-0.000522)=-0.301522$.

c. The effect of the total level of education on poverty levels through economic growth of districts/cities in Bali Province is equal to $-0.764+(-0.000354)=-0.764354$. follows:

The path diagram of the direct relationship between the research variables is as

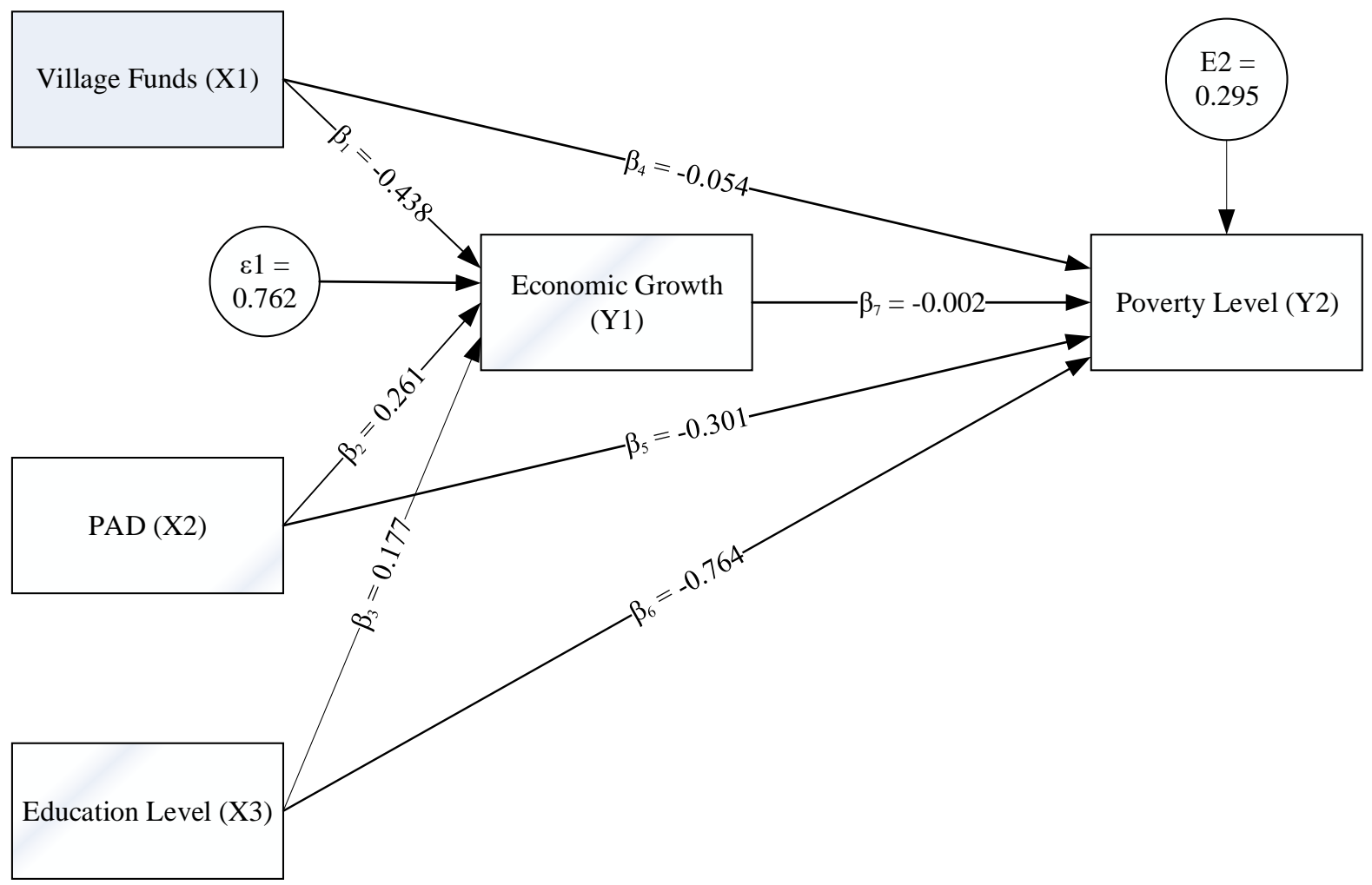

Figure 2 - Path diagram of direct relationship between research variables

Analyzing the indirect effect of the research variables through the mediating variable, the mediation or intervening tests are carried out. Analysis of the direct effect, indirect effect, and total effect of the studied variables is shown to determine the strength of the influence between variables, direct, indirect and total effects. Based on the calculation, it can be seen the amount of direct influence and indirect effect between variables. The direct and indirect effects as well as the total influence of village funds $\left(X_{1}\right)$, PAD $\left(X_{2}\right)$, education level $\left(X_{3}\right)$, economic growth $\left(Y_{1}\right)$ on the poverty level $\left(Y_{2}\right)$ shown as follows:

Table 8 - Variable Analysis

\begin{tabular}{lllllllllll}
\hline \multirow{2}{*}{ VARIABLE } & & $\mathrm{X}_{1}$ & & \multicolumn{3}{c}{$\mathrm{X}_{2}$} & \multicolumn{3}{c}{$\mathrm{X}_{3}$} & $\mathrm{Y}_{1}$ \\
& $\mathrm{PL}$ & $\mathrm{PTL}$ & $\mathrm{PT}$ & $\mathrm{PL}$ & $\mathrm{PTL}$ & $\mathrm{PT}$ & $\mathrm{PL}$ & $\mathrm{PTL}$ & $\mathrm{PT}$ & $\mathrm{PL}$ \\
\hline $\mathrm{Y}_{1}$ & -0.438 & - & - & 0.261 & - & - & 0.177 & - & - & - \\
$\mathrm{Y}_{2}$ & -0.054 & 0.0008 & -0.053 & -0.301 & -0.0005 & -0.3015 & -0.764 & -0.0003 & -0.7643 & -0.002 \\
\hline
\end{tabular}


To calculate the variance of the variables which not examined in the model $\left(e_{1}\right.$ and $\left.e_{2}\right)$ can be done as follows:

$$
\begin{aligned}
& \text { Error term } 1\left(e_{1}\right)=\sqrt{ }\left(1-R^{2}\right)=0.76223356 \\
& \text { Error term } 2\left(e_{2}\right)=\sqrt{ }\left(1-R^{2}\right)=0.294957624
\end{aligned}
$$

Examination of the model validity is done by calculating the total coefficient of determination with the following calculations: $R_{m}^{2}=1-P_{e 1}^{2} P_{e 2}^{2} \ldots P_{e p}^{2}=0.9495$.

Based on the results above, means that the diversity of data can be explained by the model formed is 94.95 percent, while the remaining 5.05 percent is explained by other variables outside the model formed.

Based on the results of processed data, it appears that village funds have negative and significant effect on economic growth of districts/cities in Bali Province. The PAD variable and education level have positive and insignificant effect on economic growth of districts/cities in Bali Province, the regression equation written as follows:

$$
Y_{1}=5.744-0.438 X_{1}+0.261 X_{2}+0.177 X_{3}+e_{1}
$$

\begin{tabular}{|c|c|c|c|c|c|c|}
\hline \multirow{3}{*}{$\frac{\text { Model }}{1}$} & \multicolumn{2}{|l|}{ Unstandardized Coefficients } & \multicolumn{4}{|c|}{ Standardized Coefficients } \\
\hline & B & Std. Error & Beta & & $\mathrm{t}$ & Sig. \\
\hline & (Constant) & 5.744 & .319 & & 17.991 & .000 \\
\hline & $\mathrm{DD}\left(\mathrm{X}_{1}\right)$ & $-6.151 \mathrm{E}-6$ & .000 & -.438 & -3.568 & .001 \\
\hline & $\operatorname{PAD}\left(\mathrm{X}_{2}\right)$ & 8.895E-8 & .000 & .261 & 1.813 & .077 \\
\hline & Education Level $\left(\mathrm{X}_{3}\right)$ & .045 & .037 & .177 & 1.208 & .234 \\
\hline \multicolumn{7}{|c|}{ a. Dependent Variable: Economic Growth $\left(\mathrm{Y}_{1}\right)$} \\
\hline
\end{tabular}

Information: $Y_{1}$ is economic growth; $X_{1}$ is the village fund; $X_{2}$ is PAD; $X_{3}$ is education level.

Based on the results of processed data, it can be seen that village funds, PAD, education level, and economic growth have a negative effect on poverty levels of districts/cities in Bali Province, but the village funds variable and economic growth have a negative and insignificant effect on poverty levels of districts/cities in Bali. PAD variables and education level have a negative and significant effect on poverty levels of districts/cities in Bali Province, the regression equation written as follows:

$$
Y_{2}=11.292-0.054 X_{1}-0.301 X_{2}-0.764 X_{3}-0.002 Y_{1}+e_{1}
$$

\begin{tabular}{|c|c|c|c|c|c|c|}
\hline \multirow{2}{*}{ Model } & \multicolumn{2}{|l|}{ Unstandardized Coefficients } & \multicolumn{4}{|c|}{ Standardized Coefficients } \\
\hline & B & Std. Error & Beta & & $t$ & Sig. \\
\hline$\overline{1}$ & (Constant) & 11.292 & 1.428 & & 7.906 & .000 \\
\hline & $\mathrm{DD}\left(\mathrm{X}_{1}\right)$ & $-2.901 \mathrm{E}-6$ & .000 & -.054 & -.980 & .333 \\
\hline & $\operatorname{PAD}\left(\mathrm{X}_{2}\right)$ & $-3.931 \mathrm{E}-7$ & .000 & -.301 & -5.140 & .000 \\
\hline & Education Level $\left(\mathrm{X}_{3}\right)$ & -.749 & .057 & -.764 & -13.095 & .000 \\
\hline a. Dep & $\begin{array}{l}\text { Economic Growth }\left(\mathrm{Y}_{1}\right) \\
\text { dent Variable: Poverty Level }\end{array}$ & $\begin{array}{l}-.008 \\
\left.Y_{2}\right)\end{array}$ & .234 & -.002 & -.035 & .973 \\
\hline
\end{tabular}

Information: $Y_{2}$ is the poverty level; $Y_{1}$ is economic growth; $X_{1}$ is the village fund; $X_{2}$ is PAD; $\mathrm{X}_{3}$ is the level of education.

Testing of intervening variables is carried out using the Sobel test as follows:

1) Hypothesis:

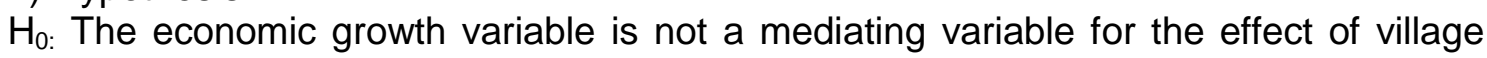
funds, PAD, and education level on poverty levels.

$\mathrm{Hi}$ : Economic growth variable as a mediating variable for the effect of village funds, PAD, and education level on poverty levels. 
2) Testing criteria:

- If $p$-value $\geq$ alpha $(0.05)$, or $z$ count $\leq(z$ table $=1.96)$, then Ho is accepted, which means $M$ is not the mediating variable.

- If the $p$-value <alpha $(0.05)$, or $z$ count $>(z$ table $=1.96)$, then Ho is rejected, which means $M$ is the mediating variable.

3) Test statistics:

Economic growth does not significantly mediate the effect of village funds, PAD, and education levels on poverty levels. This can be seen from the results of the $z$ count which is smaller than 1.96, which means that $\mathrm{Ho}$ is accepted and economic growth is not a mediating variable for the effect of village funds, PAD, and the level of education on poverty levels.

\section{DISCUSSION OF RESULTS}

1. The effect of village funds, PAD, and education level on economic growth of districts/cities in Bali Province:

a. The influence of village funds on economic growth.

The relationship between village funds and economic growth has a path coefficient of 0.438 and a significance level of 0.001 less than 0.05 , which means that village funds have no positive but significant effect on economic growth. This is not in accordance with the hypothesis that village funds have a positive effect on economic growth.

The implementation action of the village fund activities are directed to be carried out in a self-managed manner with a labor-intensive program with a cash-for-work scheme aimed at increasing the purchasing power of rural communities has not been implemented properly. This can be seen in the implementation of development that still being carried out by third parties using labor from outside the region, so that it cannot absorb local village labor. The implementation of village development cannot absorb local labor and does not provide income to the village community indirectly, so it cannot increase the people's purchasing power. Based on an in-depth interview with Ida Ayu Kade Krisna Astuti, SE., M.Sc., this is in line with research conducted by Sitepu (2019), that the trickle down effect concept does not apply to the district.

b. The influence of PAD on economic growth.

In this study, the relationship between PAD and economic growth has a path coefficient of 0.261 and a significance level of 0.077 , greater than 0.05 , which means that PAD has a positive but insignificant effect on economic growth. This is in accordance with the hypothesis that PAD has a positive effect on economic growth, but it is not statistically significant.

The higher PAD realization will increase the independence of the region in managing and implementing program activities aimed at improving community welfare. This is in line with research (Jolianis, 2016), where an increase in PAD will trigger and spur regional economic growth to be better than the previous regional economic growth.

c. Effect of education level on economic growth.

In this study, the relationship between education level and economic growth has a path coefficient of 0.177 and a significance level of 0.234 , greater than 0.05 , which means that the level of education has a positive and insignificant effect on economic growth.

These results are in line with the research hypothesis, that the education level has a positive effect on economic growth, but not statistically significant. This is influenced by human resources who graduated from high school or above choose to go to cities to find jobs that more promising and give higher income than their home regions. Badung Regency, Denpasar City, and Gianyar Regency are the destination areas for people in the other six districts to get jobs and better income. These phenomena will be difficult for economic growth in the home region to increase due to the loss of production factors in the form of labor.

2. The effect of village funds, PAD, education level, and economic growth on poverty levels of districts/cities in Bali Province. 
a. The effect of village funds on poverty levels.

In this study, the relationship between village funds and poverty levels has a path coefficient of -0.054 and a significance level of 0.333 , greater than 0.05 , which means that village funds have a negative and insignificant effect on poverty levels. This result is in line with the research hypothesis which states that village funds have a negative effect on poverty levels, but not significantly.

The use of village funds for empowerment has not been implemented optimally where empowerment only focuses on the implementation of activities that have been budgeted for in the APBDes, but does not pay attention to the output of the implementation of the coaching. The empowerment program has not been maximally targeting the poor because there are still elements in the village government who are not objective in collecting data on the village poor. This result is supported by Sitepu's research (2019).

b. The effect of PAD on poverty levels.

In this study, the relationship between PAD and poverty level has a path coefficient of 0.301 and a significance level of 0.000 , less than 0.05 , which means that PAD has a negative and significant effect on poverty levels. This is in accordance with the hypothesis that PAD has a negative effect on poverty levels and is statistically significant.

The higher the PAD, the better the level of regional independence where the regions are more flexible to carry out program activities aimed at reducing poverty.

c. Effect of education level on poverty levels.

In this study, the relationship between the poverty level and the poverty level has a path coefficient of -0.764 and a significance level of 0.000 less than 0.05 , which means that the poverty level has a negative and significant effect on the poverty level. This result is in line with the research hypothesis which states that education level has a negative effect on poverty levels.

The higher the average length of schooling, the more the population has the better education. Education can teach workers about skills that can increase productivity and workers will get higher income as well (Becker, 1985). Education can provide a way out of the poverty trap by allowing access to higher income and meeting basic needs. The higher the level of education, the higher the chances of getting out of the poverty line (Awan ddk., 2011). Investments in infrastructure and education have had a very high impact on poverty reduction in rural areas of Uganda (Fan, 2004). The results of this study are in line with the research of Wibowo (2014), Aristina (2017), Azizah (2018), and Adi Parwa (2019) which concluded that education level has a negative effect on poverty levels. The higher the level of education possessed by the community, the higher the competency possessed by the community. This will affect the level of community income. As long as the level of income is high, people can avoid poverty. An increase in the percentage of working age with a better level of education has the potential to promote economic growth and reduce poverty (Cruz, 2018).

d. The effect of economic growth on poverty levels.

In this study, the relationship between economic growth and poverty level has a path coefficient of -0.002 and a significance level of 0.973 , greater than 0.05 , which means that economic growth has a negative and insignificant effect on poverty levels. This is in line with the research hypothesis that economic growth has a negative effect on poverty levels, but it is not statistically significant.

The results showed that economic growth had no effect on the poverty level because it was influenced by income inequality between districts/cities in Bali Province. A low income will caused low economic growth which consequence in low welfare level which affects to increase the poverty level. The economic growth of Bali Province in 2015-2019 has always been above the national economic growth, but this does not indicate inclusive economic growth, which is seen in income inequality and poverty rates.

Economic growth appears to be a necessary but insufficient condition for poverty alleviation, this must be accompanied by other factors such as policies to reduce inequality (Aleman, 2018). Inequality has a negative effect on economic growth, especially concentrated in countries with high poverty levels (Breunig, 2020). The results of this study 
are supported by research by Manek (2016), in which economic growth has no significant negative effect on the poverty of districts / cities in East Nusa Tenggara Province, which is due to high economic growth which is not accompanied by equal distribution of income which can lead to regional disparities so as to create a poverty gap.

According to Akinci's (2016) research, increasing the income of the rich increases the income of the poor and vice versa. However, the contribution of the transfer of income of the poor to the rich is more dominant than the other way around. Inequality of income distribution will cause the rich to get richer, and the poor to become poorer. This is supported by the research of Bacarreza (2018), where economic growth is usually associated with a reduction in poverty levels and an increase in the middle class, but the impact of economic growth on average income and poverty rates is not always the same across countries or even within a country. Economic growth caused by the growth of different sectors also results in a reduction in the level of poverty that is different. Research conducted by Ravallion and Datt (1996) in India, found that growth in agriculture and in particular in the service sector had a higher impact on poverty reduction than growth in the manufacturing sector.

Based on developments and trends in gross domestic product (GDP), income distribution, and poverty, economically strong regions (or their populations) are better at dealing with poverty during crisis periods (Michalek, 2018). Policies are needed to reduce income inequality so that the poor can benefit from economic growth (Adelowokan et al, 2019).

3. The indirect effect of village funds, PAD, and education levels on poverty levels through economic growth of districts/cities in Bali Province.

Based on the results of the study, there are several indirect effects between exogenous and endogenous variables. These influences include as follows:

a. The indirect effect of village funds on poverty levels through economic growth.

Based on the research results obtained beta coefficient $=\beta_{1} \times \beta_{6}=-0.438 \times-0.002=$ 0.000876 . Based on the Sobel test, the results of the study are not in accordance with the hypothesis, that village funds have an indirect effect on poverty levels through economic growth of districts/cities in Bali Province.

b. The indirect effect of PAD on poverty levels through economic growth.

Based on the research results obtained beta coefficient $=\beta_{2} \times \beta_{6}=0.261 \times-0.002=-$ 0.000522 . Based on the Sobel test, the results of this study are not in accordance with the hypothesis, that PAD has an indirect effect on poverty levels through economic growth of districts/cities in Bali Province.

c. The indirect effect of education level on poverty levels through economic growth.

Based on the research results obtained beta coefficient $=\beta_{3} \times \beta_{6}=0.177 \times-0.002=-$ 0.000354 . Based on the Sobel test, the results of the study are not in accordance with the hypothesis, that the education level has an indirect effect on the level of poverty through economic growth of districts/cities in Bali Province.

Research Limitations. The limitations in this study are the time series data used is limited to only five years due to the provision of new village funds starting in 2015 and the limited number of respondents who were interviewed in depth related to problems in the study due to the COVID-19 pandemic outbreak.

\section{CONCLUSION}

Based on the research objectives and discussion of the research results, can be concluded as follows:

1. PAD and education level variables have a positive but insignificant effect on economic growth, but village funds have no positive and significant effect on economic growth of districts/cities in Bali Province;

2. The village funds, PAD, education level, and economic growth variables have a negative effect on the poverty level of districts/cities in Bali Province, where statistically PAD and education level have a significant effect, while DD and economic growth have no significant effect; 
3. Indirectly, the variables of village funds, PAD, and education level do not have a significant effect on poverty levels through economic growth of districts/cities in Bali Province.

Efforts to support poverty alleviation and income distribution in realizing inclusive economic development in districts/cities in Bali Province are determined by the role of the government, society and related parties, namely.

Government. The village government as the subject of village development based on the Village Law is expected to be able to manage village funds in accordance with the policy direction of the central government regarding the allocation of village funds and the utilization of local resources, namely the use of raw materials and local labor in the implementation of village development. The need for development synergy between the village and district / city, provincial and central governments to accelerate equitable development starting from the planning, implementation and evaluation stages. The village government must be able to exploit all regional potential, economic, social and cultural potential in the village through policies and programs that aim to reduce inequality, create job opportunities, increase income, and improve community welfare with real action, work - profit - save. The village government must be able to empower village communities by creating at least one superior village product that can be widely traded to improve the welfare of the people involved in it.

District / city governments in an effort to increase revenue through PAD are required to create new sources of economic growth that are not only based on the tourism industry. The Provincial Government of Bali also needs to carry out equitable development of infrastructure that can support economic growth with the principle of absorbing local labor in the implementation of its development and is sustainable.

Society. People with higher levels of education are expected to be able to contribute in developing their own regions, one of which is by creating jobs in the regions either independently or by involving investors from outside the region. Increasing employment opportunities will reduce the flow of urbanization to the city and encourage local people to work in their respective areas of origin. The poor are expected to participate by supporting and making good use of poverty alleviation programs carried out by the government. Every community must be able to support themselves with a simple concept, namely one person one product, where everyone must have a product that can be exchanged economically, so that each has an income or income. The income is used to meet consumption needs and partly for savings so that each individual is encouraged to be independent and not become a burden to other parties. By increasing income, it will encourage an increase in purchasing power which will increase economic growth and reduce poverty.

\section{REFERENCES}

1. Adi Parwa, IGN Jana Loka, and IGW Murjana Yasa. 2019. Pengaruh Tingkat Pendidikan and Investasi Terhadap Pertumbuhan Ekonomi and Kemiskinan di Provinsi Bali. E-Jurnal Ekonomi Pembangunan Universitas Udayana. 8(5), 945-973.

2. Adelowokan, Oluwaseyi Adedayo, Olukayode Emmanuel Maku, Awoyemi Olayiwola Babasanya, and Adesola Bolaji Adesoye. 2019. Unemployment, Poverty and Economic Growth in Nigeria. Journal of Economics and Management. 35(1), 5-17.

3. Akinci, Merter. 2015. Inequality and Economic Growth: Trickle-Down Effect Revisited. Development Policy Review. 36(Issue S1), 01-O24.

4. Aleman, Paula Andrea Nieto, Norat Roig-Tierno, Francisco Mas-Verdú, and JoséMaría García Álvarez-Coque. 2018. Multidimensional Paths to Regional Poverty: A Fuzzy-set Qualitative Comparative Analysis of Colombian Departments. Journal of Human Development and Capabilities. 19(4), 499-520.

5. Amalia, Fitri. 2013. Analisis Pengaruh Variabel-Variabel Pendidikan Terhadap Pertumbuhan Ekonomi Di Kawasan Timur Indonesia dengan Pendekatan Human Capital Model. Semnas Fekon: Optimisme Ekonomi Indonesia 2013, Antara Peluang and Tantangan. 
6. Anderson, Courtney Lauren. 2013. Opening Doors: Preventing Youth Homelessness Through Housing and Education Collaboration. Seattle Journal for Social Justice. 11(2), 457-522.

7. Aristina, Ita, Made Kembar Sri Budhi, I.G.A.P. Wirathi, and Ida Bagus Darsana. 2017. Pengaruh Tingkat Pendidikan, Pengangguran and Pertumbuhan Ekonomi Terhadap Kemiskinan di Provinsi Bali. E-Jurnal Ekonomi Pembangunan Universitas Udayana. 6(5), 677-704.

8. Arsyad, Lincolin. 2016. Pengantar Perencanaan Pembangunan Ekonomi Daerah. Yogyakarta: BPFE Yogyakarta.

9. Awan, M. S., N. Malik, H. Sarwar, and M. Waqas. 2011. Impact of Education on Poverty Reduction. International Journal of Academic Research. 3 (1), 659-664

10. Azizah, Elda Wahyu, Sudarti, Hendra Kusuma. 2018. Pengaruh Pendidikan, Pendapatan Perkapita and Jumlah Penduduk Terhadap Kemiskinan di Provinsi Jawa Timur. Jurnal Ilmu Ekonomi. 2(1), 167-180.

11. Bacarreza, Gustavo Canavire, Michael Jetter, and Marcos Robles. 2018. When Does Economic Growth Reduce Poverty and Strengthen the Middle Class? A State-Level, Sector-Specific Analysis of Peru. Southern Economic Journal. 84(4):1067-1087.

12. Badan Pusat Statistik Republik Indonesia. 2020a. Tabel Jumlah Penduduk Miskin Menurut Provinsi, 2007-2020. Jakarta: Badan Pusat Statistik Republik Indonesia.

13. 2020b. Tabel Persentase Penduduk Yang Hidup di Bawah Garis Kemiskinan Nasional, Menurut Daerah Tempat Tinggal. Jakarta: Badan Pusat Statistik Republik Indonesia.

14. Badan Pusat Statistik Provinsi Bali. 2020. Provinsi Bali Dalam Angka 2020. Bali: Badan Pusat Statistik Provinsi Bali.

15. Becker, Gary S. 1985. Human Capital, Effort, and the Sexual Division of Labor. Journal of Labor Economics. 3(1), S33-S58.

16. Breunig, Robert, and Omer Majeed. 2020. Inequality, Poverty and Economic Growth. International Economics. 161(May 2020), 83-99.

17. Cruz, Marcio and S. Amer Ahmed. 2018. On The Impact of Demographic Change on Economic Growth and Poverty. World Development. 105 (May 2018), 95-106.

18. Direktorat Jenderal Perimbangan Keuangan. 2018. Ringkasan APBD 2018. Direktorat Jenderal Perimbangan Keuangan.

19. 2020. APBD Pemerintah Daerah. http://www.djpk.kemenkeu.go.id/portal/data/apbd (accessed on 21 April 2020).

20. Fan, Shenggen, Xiaobo Zhang, and Neetha Rao. 2004. Public Expenditure, Growth, and Poverty Reduction in Rural Uganda. DSGD Discussion Paper No. 4. International Food Policy Research Institute

21. Ghozali, Imam. 2008. Model Persamaan Struktural Konsep and Aplikasi dengan Program AMOS 16.0. Semarang: Badan Penerbit Universitas Diponegoro

22. Jolianis. 2016. Analisis Pengaruh PAD, DAU and DAK Terhadap Kemiskinan pada Kabupaten/Kota di Provinsi Sumatera Barat dengan Pertumbuhan Ekonomi sebagai Variabel Intervening. Journal of Economic and Economic Education. 4(2), 192-209.

23. Kementerian Keuangan Republik Indonesia. 2017a. Buku Saku Dana Desa; Dana Desa untuk Kesejahteraan Rakyat. Jakarta: Kementerian Keuangan Republik Indonesia.

24. 2017b. Buku Pintar Dana Desa; Dana Desa untuk Kesejahteraan Rakyat. Cetakan Pertama. Jakarta: Kementerian Keuangan Republik Indonesia.

25. 2019. Buku Pintar Dana Desa; Dana Desa untuk Kesejahteraan Rakyat. Cetakan Kedua. Jakarta: Kementerian Keuangan Republik Indonesia.

26. Kuncoro, Mudrajad. 1997. Ekonomi Pembagunan (Teori, Masalah, and Kebijakan). Yogyakarta: UPP STIM YKPN.

27. 2018. Perencanaan Pembangunan Daerah: Teori and Aplikasi. Jakarta: PT Gramedia.

28. 2019. Ekonomika Desa: Teori, Strategi \& Realisasi Pembangunan Desa. Yogyakarta: UPP STIM YKPN.

29. Mahaendra Yasa, Nyoman, Made Kembar Sri Budhi, and Paulus Kurniawan. 2018. Being Smart in Microeconomics and Macroeconomics. Denpasar: Ikatan Doktor Ekonomi Udayana. 
30. Manek, Marianus and Rudy Badrudin. 2016. Pengaruh Pendapatan Asli Daerah and Dana Perimbangan Terhadap Pertumbuhan Ekonomi and Kemiskinan di Provinsi Nusa Tenggara Timur. Telaah Bisnis. 17(2), 81-98.

31. Margareni, Ni Putu Ayu Purnama, I Ketut Djayastra, IGW Murjana Yasa. 2016. FaktorFaktor yang Mempengaruhi Kemiskinan di Provinsi Bali. Jurnal Piramida. XII(1), 101-110.

32. Menteri Dalam Negeri RI. 2014. Peraturan Menteri Dalam Negeri Republik Indonesia Nomor 114 Tahun 2014 tentang Pedoman Pembangunan Desa. Berita Negara RI Tahun 2014 Nomor 2094. Jakarta: Menteri Hukum and Hak Asasi Manusiarepublik Indonesia.

33. Pemerintah Provinsi Bali. (2014).Peraturan Daerah Provinsi Bali Nomor 1 Tahun 2014 tentang RPJMD Provinsi Bali 2013-2018. Denpasar: Pemerintah Daerah Provinsi Bali.

34. 2019. Peraturan Daerah Provinsi Bali Nomor 3 Tahun 2019 tentang RPJMD Semesta Berencana Provinsi Bali 2018-2023. Denpasar: Pemerintah Provinsi Bali.

35. Pemerintah Republik Indonesia. 2003. Undang-Undang Nomor 17 Tahun 2003 tentang Keuangan Negara. Lembaran Negara RI Tahun 2003 Nomor 47. Jakarta: Sekretariat Negara.

36. 2003. Undang-Undang Nomor 20 Tahun 2003 tentang Sistem Pendidikan Nasional. Lembaran Negara RI Tahun 2003 Nomor 78. Jakarta: Sekretariat Negara.

37. 2004. Undang-Undang No. 25 Tahun 2004 tentang Sistem Perencanaan Pembangunan Nasional. Lembaran Negara RI Tahun 2004 Nomor 104. Jakarta: Sekretariat Negara.

38. 2004. Undang-Undang Nomor 33 Tahun 2004 tentang Perimbangan Keuangan Antara Pusat and Daerah. Lembaran Negara RI Tahun 2004 Nomor 126. Jakarta: Sekretariat Negara.

39. 2009. Undang-Undang Nomor 28 Tahun 2009 tentang Pajak Daerah and Retribusi Daerah. Lembaran Negara RI Tahun 2009 Nomor 130. Jakarta: Sekretariat Negara.

40. 2014. Undang-Undang No. 6 Tahun 2014 tentang Desa. Lembaran Negara RI Tahun 2014 Nomor 7. Jakarta: Sekretariat Negara.

41. 2014. Undang-Undang No. 23 Tahun 2014 tentang Pemerintah Daerah. Lembaran Negara RI Tahun 2014 Nomor 244. Jakarta: Sekretariat Negara.

42. 2015. Peraturan Pemerintah Republik Indonesia Nomor 47 Tahun 2015 tentang Perubahan atas Peraturan Pemerintah Nomor 43 Tahun 2014 tentang Peraturan Pelaksanaan Undang-Undang Nomor 6 Tahun 2014 Tentang Desa. Lembaran Negara RI Tahun 2015 Nomor 157. Jakarta: Sekretariat Negara.

43. Pratiwi, Seruni and Ketut Sutrisna. 2014. Pengaruh PDRB Perkapita, Pendidikan, and Produktivitas Tenaga Kerja Terhadap Kemiskinan di Provinsi Bali. E-Jurnal Ekonomi Pembangunan Universitas Udayana. 3(10), 431-439.

44. Ravallion, Martin and Gaurav Datt. 1996. How Important to India's Poor Is the Sectoral Composition of Economic Growth?. World Bank Economic Review. 10(1), 1-25.

45. Suyana Utama, Made. 2016. Buku Ajar Aplikasi Analisis Kuantitatif untuk Ekonomi and Bisnis. Denpasar: Universitas Udayana.

46. Todaro, Michael P. and Stephen C. Smith. 2006. Pembangunan Ekonomi, Edisi Kesembilan. (D. Barnadi, Ed., \& H. Munandar, Trans.). Jakarta: Penerbit Erlangga.

47. Wibowo, Dian Adi. 2014. Pengaruh Pembiayaan Pendidikan, Tingkat Pendidikan, Pertumbuhan Ekonomi and Kemiskinan di Jawa Tengah. Jurnal Ekonomia. 10(2), 133140. 